\section{Effect of Polymerization Cycles on Gloss, Roughness, Hardness and Impact Strength of Acrylic Resins}

\author{
Rafael Leonardo Xediek Consani' ${ }^{1}$, Bianca L. Folli², Moises C. F. Nogueira², \\ Americo Bortolazzo Correr ${ }^{3}$, Marcelo F. Mesquita ${ }^{1}$
}

\author{
'Department of Prosthodontics \\ and Periodontology, Dental \\ School of Piracicaba, UNICAMP \\ - Universidade Estadual de \\ Campinas, Piracicaba, SP, Brazil \\ ${ }^{2}$ Dental School of Piracicaba, \\ UNICAMP - Universidade Estadual \\ de Campinas, Piracicaba, SP, Brazil \\ ${ }^{3}$ Department of Restorative Dentistry, \\ Dental School of Piracicaba, \\ UNICAMP - Universidade Estadual \\ de Campinas, Piracicaba, SP, Brazil
}

Correspondence: Rafael Leonardo Xediek Consani, Avenida Limeira 901, 13414-903 Piracicaba, SP, Brasil. Tel: +55-19-2106-5296. e-mail: rconsani@fop.unicamp.br

Key Words: acrylic resin, polymerization cycle, physical property.

\section{Introduction}

Since the 1930's, acrylic resin based on poly (methyl methacrylate) system is the most widely used material for making conventional denture and removable partial prostheses. Several types of acrylic resins, trademarks and polymerization techniques were developed over the years, but acrylic resins can show inadequate physical properties if not properly manipulated and correctly employed. The traditional procedure for polymerization is the conventional method of hot water bath and its variations, but activation by microwave energy and visible light has also been employed (1).

Surface roughness is responsible for extrinsic pigmentation and biofilm accumulation, whereas hardness would be related to abrasiveness and wear of denture base acrylic resins. In consequence, surface roughness can enhance microorganisms adhesion, where stronger interactions occur between cells and surface features with similar dimensions, increased biofilm mass and resistance to removal. Therefore, minimization of denture abrasion during cleaning is desirable (2). The gloss is an extremely important characteristic that has effect on color perception, and it is related directly to the polishing of denture base. Thus, color stability of acrylic resins is important because there is a significant difference between perceptibility and acceptability thresholds for denture base acrylic resins (3).

Impact strength is a significant factor because longterm changes can promote softening of the acrylic resins with a negative effect on wear, abrasion and roughness. Different polymerization techniques can also influence the impact strength of denture base resins (4). The acrylic resin roughness has been used as an index of material capacity to resist the wear and abrasion, and the surface hardness test informs the material's ability to resist the penetration of a diamond point under a specific load (1).

It has been alleged that conventional laboratory polishing is the most effective polishing technique for acrylic resin denture bases (5). Maintenance of the surface gloss of acrylic resin is an important factor for the denture hygiene, due to wear from the association between tooth brushing and abrasive materials (6). Repeated mechanical cleaning procedures change the smoothness of denture bases and provide roughness favorable to colonization by microorganisms, biofilm accumulation and staining (5).

The main disadvantages of the acrylic resins for complete denture are esthetic, physical and mechanical properties that change with time in the oral environment 
and color change that affects the gloss of the denture base (7). Other variables that can change the smoothness of acrylic resins are micro porosities resulting from inadequate monomer-polymer ratio, plastic stage of the mass during packing, temperature of the polymerization cycle and viscosity of the resins (1).

Besides the factors inherent to physical properties of the acrylic resins, different polymerization protocols may influence negatively some mechanical properties $(4,8,9)$. For this reason, it would be appropriate to verify the effect of polymerization cycles (conventional and boiled) on gloss, roughness, hardness and impact strength of acrylic resins. The hypothesis of this study was that polymerization cycles would promote different effects in each property for both acrylic resins. The aim of this study was to evaluate the effect of each conventional or boiled polymerization cycle on gloss, roughness, hardness and impact strength of Classico (conventional) and QC-20 (boiled) acrylic resins.

\section{Material and Methods}

\section{Sample Preparation}

Samples $(n=10)$ were prepared for each acrylic resin by wax rectangular matrices $(65 \mathrm{~mm}$ long, $5 \mathrm{~mm}$ wide and $2 \mathrm{~mm}$ high) conventionally included in metallic flasks (Safrany; Metalurgia Safrany, São Paulo, SP, Brazil) with type III dental stone (Herodent; Vigodent, Petrópolis, RJ, Brazil) at the ratio of $100 \mathrm{~g}$ powder to $30 \mathrm{~mL}$ water, vacuum mixed for $30 \mathrm{~s}$ and poured with mechanical vibration.

The flasks remained in hydraulic press (Linea Delta; Delta, São Paulo, SP, Brazil) at $850 \mathrm{kgf}$ for $1 \mathrm{~h}$. After this, the flask was opened, the wax matrices removed and the resulting stone molds cleaned with a water-domestic detergent (Ypê; Amparo Produtos Quimicos, Amparo, SP, Brazil) solution to remove the wax residues and petroleum jelly used as dental stone isolator and washed with hot water.

The volumetric polymer-monomer ratios for Classico (Clássico Dental Products, São Paulo, SP, Brazil) and QC-20 (Dentsply, Petrópolis, RJ, Brazil) acrylic resins was according to manufacturers' instructions, using $21 \mathrm{~g}$ powder to $7 \mathrm{~mL}$ liquid. In the dough-like stage, the mixed resins were inserted in the dental stone molds isolated with a water-soluble alginate solution (Cel Lac; S.S. White, Rio de Janeiro, RJ, Brazil). A polyethylene sheet was placed over the resin, the flask reassembled and placed in a hydraulic press (Linea Delta). Pressures of $850 \mathrm{kgf}$ for $5 \mathrm{~min}$ and $1,250 \mathrm{kgf}$ for $20 \mathrm{~min}$ applied incrementally were used for initial and final pressings, respectively. Classico acrylic resin polymerization procedure was in an automatic apparatus (Thermotron; Thermotron Dental Products, Piracicaba, SP, Brazil), set for a heated water cycle at $74^{\circ} \mathrm{C}$ for $9 \mathrm{~h}$. $\mathrm{QC}-20$ acrylic resin polymerization procedure was performed in hot water for $20 \mathrm{~min}$.

Sample deflasking was accomplished after flask cooling at room temperature. Afterwards the sample surface was abraded with silicon carbide sandpapers (Norton, São Paulo, SP, Brazil) with decreased granulation (200, 400 and 600), and polishing was made with magnesium and calcium carbonate slurry (Pasom; Pasom Dental Materials, São Paulo, SP, Brazil) followed by a universal polishing slurry based on aluminum oxide (Kota, Cotia, SP, Brazil).

\section{Gloss Evaluation}

The gloss-meter measurement principle is based on a light beam incident on the sample surface. The intensity of the reflected light is measured and compared with a reference value. The gloss-meter calibration was made with a highly polished black glass pattern supplied by manufacturer. Gloss values for Classico and QC-20 acrylic resins were measured with gloss-meter (Multi Gloss 268; Konica Minolta, Ramsey, NJ, USA) using a light incidence of $60^{\circ}$. Four measurements were made on each sample and the arithmetic mean was considered the gloss value (Gloss Unit - GU).

\section{Roughness Evaluation}

Classico and QC-20 samples were submitted to a profilometer (Surfcorder SE 1700; Kosaka, Tokyo, Japan) for surface roughness evaluation. The considered value was the arithmetic mean ( $\mathrm{Ra}$ ) of the highest peak and the deepest valley in a $2.4 \mathrm{~mm}$ measuring path, a $0.8 \mathrm{~mm}$ wavelength and a $0.5 \mathrm{~mm} / \mathrm{s}$ speed. Three measurements were made in each sample and the arithmetic mean was considered the roughness value (Ra- $\mu \mathrm{m})$.

\section{Knoop Hardness Evaluation}

Indentations were accomplished in Classico and QC20 samples with a durometer (HMV-2; Shimadzu, Tokyo, Japan) using a $50 \mathrm{gf}$ load for $10 \mathrm{~s}$. Knoop hardness value was considered as the arithmetic mean of three indentations made on each sample, located at the center and at each end (16 $\mathrm{mm}$ distance among them).

\section{Impact Strength Evaluation}

Classico and QC-20 samples were submitted to impact strength test in an Otto Wolpert-Werke device (Frankfurt, Germany) by Charpy system $(40 \mathrm{kpcm})$. The value of impact obtained for the fractured sample was changed for impact strength using the formula

$$
\mathrm{IS}=\mathrm{Ir} / \mathrm{wh} \text {, }
$$

where: IS= impact strength; Ir= impact realized $(\mathrm{kpcm})$; $\mathrm{W}=$ sample width in the impact region $(\mathrm{cm}) ; \mathrm{h}=$ sample height at the impact region $(\mathrm{cm})$. 


\section{Statistical Analysis}

Data of gloss, hardness, roughness and impact strength were evaluated for normality by Kolmogorov-Smirnov and the heterocedasticity of variances by Levene's test. Data distribution was normal and the variances were homogeneous, except for hardness. The comparison of gloss, roughness and impact strength was performed by Student's t-test. The comparison of hardness values was made by Mann-Whitney's test. A significance level of 5\% was set for all analyses.

\section{Results}

Table 1 shows the mean values and standard deviations (SD) for gloss, roughness, hardness and impact strength of the Classico (conventional) and OC-20 (boiled) thermoactivated acrylic resins. The effects of the polymerization cycles on the evaluated properties were statistically similar for both acrylic resins.

\section{Discussion}

The current study evaluated the effect of polymerization cycles on gloss, roughness, hardness and impact strength of each Classico (conventional) or QC-20 (boiled) acrylic resins. Table 1 shows that there were no statistically significant differences for polymerization cycle-resin interaction when these properties were evaluated. In these conditions, the hypothesis of this study that polymerization cycles would promote different effects in each property for both acrylic resins was not accepted.

This result is not similar to a previous study showing that linear dimensional change, hardness and impact strength of acrylic resins were differently affected by four different polymerization cycles, when the samples were deflasked immediately or after water storage for 7 and 30 days (8). In addition, there were significant differences in surface roughness between conventional $\left(9 \mathrm{~h}\right.$ at $74^{\circ} \mathrm{C}$ ) and short ( 1 h at $74^{\circ} \mathrm{C}+30 \mathrm{~min}$ at $100^{\circ} \mathrm{C}$ ) curing cycles (9). Different effects on the linear dimensional change, hardness and impact strength of acrylic resins were observed under the influence of different polymerization cycle-water storage

Table 1. Means and standard deviations for Classico and QC-20 acrylic resins related to evaluated properties

\begin{tabular}{|c|c|c|c|c|c|c|c|c|}
\hline & \multicolumn{2}{|c|}{ Gloss } & \multicolumn{2}{|c|}{ Roughness } & \multicolumn{2}{|c|}{ Hardness } & \multicolumn{2}{|c|}{$\begin{array}{l}\text { Impact } \\
\text { strength }\end{array}$} \\
\hline & Mean & SD & Mean & SD & Mean & SD & Mean & SD \\
\hline Classico & 67.7 & 10.8 a & 0.8742 & $0.4280 \mathrm{a}$ & 27.4 & $3.6 \mathrm{a}$ & 37.6 & $10.4 \mathrm{a}$ \\
\hline \multirow[t]{2}{*}{ QC-20 } & 62.2 & $5.1 \mathrm{a}$ & 1.4694 & $0.8852 \mathrm{a}$ & 26.9 & $0.9 \mathrm{a}$ & 33.6 & $9.7 \mathrm{a}$ \\
\hline & \multicolumn{2}{|c|}{$p=0.161$} & \multicolumn{2}{|c|}{$p=0.072$} & \multicolumn{2}{|c|}{$\mathrm{p}=0.910$} & \multicolumn{2}{|c|}{$\mathrm{p}=0.391$} \\
\hline
\end{tabular}

Same lowercase letters in columns do not differ by Student's t-test $(\mathrm{p}<0.005)$. associations (10). When a high impact heat-cured acrylic resin was polymerized in autoclave and conventional methods, there were significant differences between techniques in transverse, impact, hardness and porosity values. The slow (long) curing cycle improved the physical and mechanical properties compared with the fast (short) curing cycle (11).

Despite the conventional polymerization cycle showing greater numerical values compared to the boiled method (except for roughness), there were no statistically significant differences between the acrylic resins. It is also interesting to stress the disinfection effects on the mechanical properties of acrylic resins. Thus, decreased roughness values were shown in previous studies; however, no effect was observed on the impact or flexural strength of acrylic resins submitted to single (12) or repeated (13) simulated microwave disinfections, and no significant difference in roughness was observed for acrylic resins disinfected with $1 \%$ sodium hypochlorite or $1 \%$ peracetic acid (9). In addition, flexural strength of denture base acrylic resins was significantly affected by immersion in 1\% sodium hypochlorite, $2 \%$ glutaraldehyde or $10 \%$ Micro 10 solutions for $30 \mathrm{~min}$ (14).

Another interesting fact when mechanical and biological properties were compared was that manipulation techniques (mass or saturation) and polishing methods (mechanical or chemical) showed more influence on the cytotoxicity in cell cultures than on flexural strength of denture base acrylic resins for periods of 24 to $168 \mathrm{~h}$ (15). The addition of nanostructured silver vanadate $\left(\beta-\mathrm{AgVO}_{3}\right)$ may provide the acrylic resins antibacterial activities but reduces the impact strength (16).

It is alleged that the similarity of fracture strength values of acrylic resins is due to material resilience. This mechanical property has been considered similar for different acrylic resin materials $(12,17)$. This was also observed in the current study, as there was no statistically significant difference for impact strength values in both polymerization cycles. Conversely, it has been shown that short and long curing cycles by water bath, pressure cooker and microwave technique produce different effects on the impact strength of denture base acrylic resins. There was statistically significant difference in the impact strength for denture base resins polymerized using long cycle and short curing cycle in each technique, with better results for the long curing process. In addition, denture base resin polymerized by microwave activation technique showed the highest impact strength value when related to short and long water bath curing cycles 
or pressure cooker (4).

Surface gloss and surface roughness are time-dependent characteristics influenced by polishing procedures and applied force (18). A study analyzing six mechanical and chemical polishing techniques (Resilit high-luster polishing liquid, Universal polishing paste, Abraso-star K50, Pumice, Jet seal liquid and Acrypoint) on the surface roughness of heat- and light-cured denture base acrylic resins showed that the mechanical polish produced the smoothest surface, while the surface roughness values produced by these procedures were not influenced by the type of acrylic resin (19). In addition, the difference between smooth polished and rough unpolished resin surfaces was statistically significant, and it was also found that the gloss of heat-polymerized denture base resin was affected by immersion in four beverage solutions, showing noticeable gloss changes (7).

Surface gloss seems to be more consistent than roughness, despite the close association between these properties (18). Considering that the polishing time and load applied on the samples were standardized in the study, this may possibly explain the statistically similar results. As the surface smoothness and gloss levels are considered dependent on material hardness (20), the results observed in the present study followed the same pattern in relation to these acrylic resin properties. In other words, less rough surfaces showed greater hardness and improved gloss values. It is perhaps why a previous study (21) examined the clinical appearance (color, gloss, and surface roughness) of $\mathrm{TiO}_{2}$ coating on polymethyl methacrylate resin dentures. The surface roughness increased following $\mathrm{TiO}_{2}$ coating and afforded high levels of gloss while maintaining the color of the denture base material.

Regardless the activation mode of the acrylic resin, a stress will occur during the procedure whatever the polymerization method chosen. This fact is due to polymerization shrinkage inherent to polymeric materials (1). However, the different polymerization temperatures that occur for different curing cycles could compromise some mechanical properties, but this is a subject for further researches.

In addition, with the intention that the polymerization shrinkage promotes the least effect on the mechanical properties, denture base misfit and change in position of the teeth, some authors have developed methods and techniques in an attempt to compensate this unwanted effect. Thus, acrylic resins processed in double flask using hot water bath or microwave energy did not alter the porosity, roughness and hardness values (22). A new tension packing system was associated with decreased dimensional changes in the simulated maxillary denture bases processed by heat-polymerization (23). Different flask systems did not cause change in the distances between teeth during denture processing, and there is no evidence that different metal flask systems would promote tooth displacement with clinical significance (24). Bimaxillary flask associated to two different investing materials did not promote first molar inclination in dentures processed by microwave energy (25). In conclusion, conventional and boiled polymerization cycles produced similar effects on gloss, roughness, hardness and impact strength of both Classico and OC-20 acrylic resins.

\section{Resumo}

0 propósito neste estudo foi avaliar os ciclos de polimerização convencional e por fervura sobre o brilho, rugosidade, dureza e resistência ao impacto de resinas acrílicas. Amostras foram confeccionadas para cada resina Clássico ou QC-20 ( $n=20)$ em moldes de gesso obtidos de matrizes metálicas retangulares incluidas em muflas metálicas. A proporção monômero/polimero das resinas e manipulação foram de acordo com as recomendações dos fabricantes e a massa convencionalmente incluída em muflas metálicas. Após polimerização nos ciclos (1) convencional: 74 ${ }^{\circ} \mathrm{C}$ por 9 horas (Clássico) e (2) fervura: 20 min (QC-20), as amostras foram demufladas após esfriadas em temperatura ambiente e convencionalmente acabadas e polidas. As propriedades foram avaliadas após armazenagem das amostras em água a $37{ }^{\circ} \mathrm{C}$ por $24 \mathrm{~h}$. 0 brilho foi verificado com medidor Multi Gloss 268 (Konica Minolta), a rugosidade avaliada com rugosimetro Surfcorder SE 1700 (Kosaka), a dureza Knoop foi obtida com microdurômetro HMV-200 (Shimadzu) e a resistência ao impacto determinada pelo sistema Charpy (Otto Wolpert Werke). Os dados submetidos ao teste t de Student $(\alpha=0.05)$ mostraram que 0 s resultados foram: brilho: 67,7 e 62,2 para Clássico e $0 \mathrm{C}-20$, respectivamente; rugosidade: 0,874 e 1,469 Ra- $\mu \mathrm{m}$ para Clássico e $\mathrm{QC}-20$, respectivamente; dureza: 27,4 e 26,9 para Clássico e QC-20, respectivamente; e resistência ao impacto: 37,6 e $33,6 \mathrm{kgf} / \mathrm{cm}^{2}$ para Clássico e $0 \mathrm{C}-20$, respectivamente. Não houve diference estatisticamente significante entre as resinas para as propriedades avaliadas. Conclui-se que os ciclos de polimerização convencional e por fervura promoveram similares efeitos sobre o brilho, rugosidade, dureza e resistência ao impacto para ambas as resinas Clássico e QC-20.

\section{Acknowledgements}

The authors thank the support of CNPq/UNICAMP/PIBIC for the development of this research at Piracicaba Dental School, UNICAMP, $\mathrm{SP}$, Brazil.

\section{References}

1. Anusavice KJ. Phillips' Science of Dental Materials. 11th ed. Elsevier; 2003: 805 p.

2. Jackson S, Coulthwaite L, Loewy Z, Scallan A, Verran J. Biofilm development by blastospores and hyphae of Candida albicans on abraded denture acrylic resin surfaces. J Prosthet Dent 2014;112:988993.

3. Ren J, Lin $\mathrm{H}$, Huang $\mathrm{Q}$, Zheng G. Determining color difference thresholds in denture base acrylic resin. J Prosthet Dent 2015;114:702-708.

4. Jadhav R, Bhide SV, Prabhudesai PS. Assessment of the impact strength of the denture base resin polymerized by various processing techniques. Indian J Dent Res 2013;24:19-25.

5. Gungor H, Gundogdu M, Yesil Duymus Z. Investigation of the effect of different polishing techniques on the surface roughness of denture base and repair materials. J Prosthet Dent 2014;112:1271-1277.

6. Harrison A, Jagger DC. An in vitro investigation of the abrasive qualities of a selection of denture-cleaning pastes on poly (methyl methacrylate) denture base material. Prim Dent Care 1997;4:21-24. 
7. Keyf F, Etikan I. Evaluation of gloss changes of two denture acrylic resin materials in four different beverages. Dent Mater 2004;20:244-251.

8. Consani RLX, Vieira ML, Mesquita MF, Sinhoreti MAC, Guiraldo RD, Nóbilo MAA. Effect of polymerization cycles on the linear dimensional change, hardness and impact strength of denture base acrylic resins. Minerva Stomatol 2012;61:272-281.

9. Sczepanski F, Sczepanski CR, Berger SB, Consani RL, Gonini-Junior A, Guiraldo RD. Effect of sodium hypochlorite and paracetic acid on the surface roughness of acrylic resin polymerized by heated water for short and long cycles. Eur J Dent 2014;8:533-537.

10. Consani RLX, Chorwat V, Mesquita MF, Santos MBF, Correr AB, Consani S. Effect of simulated microwave disinfection on the linear dimensional change, hardness and impact strength of acrylic resins processed by different polymerization cycles. Minerva Stomatol 2014;63:145-154.

11. Abdulwahhab SS. High-impact strength acrylic denture base material processed by autoclave. J Prosthodont Res 2013;57:288-293.

12. Consani RL, Vieira EB, Mesquita MF, Mendes WB, Arioli-Filho JN. Effect of microwave disinfection on physical and mechanical properties of acrylic resins. Braz Dent J 2008;19:348-353.

13. Consani RL, Azevedo DD, Mesquita MF, Mendes WB, Saquy PC. Effect of repeated disinfections by microwave energy on the physical and mechanical properties of denture base acrylic resins. Braz Dent J 2009;20:132-137.

14. Savabi O, Attar K, Nejatidanesh F, Goroohi H, Badrian H. Effect of different chemical disinfectants on the flexural strength of heatpolymerized acrylic resins. Eur J Prosthodont Restor Dent 2013;21:105108.

15. Santos RL, Pithon MM, Carvalho FG, Ramos AA, Romanos MT. Mechanical and biological properties of acrylic resins manipulated and polished by different methods. Braz Dent J 2013;24:492-497.
16. Castro DT, Valente ML, Agnelli A, Lovato Silva CH, Watanabe E, Siqueira $\mathrm{RL}$, et al.. In vitro study of the antibacterial properties and impact strength of dental acrylic resins modified with a nanomaterial. J
Prosthet Dent 2016:115:238-246.

17. Oku J. Impact properties of acrylic denture base resin: 3 . Impact properties of cross-linked polymers. Dent Mater 1989;8:215-222.

18. Heintze SD, Forjanic M, Rousson V. Surface roughness and gloss of dental materials as a function of force and polishing time in vitro. Dent Mater 2006;22:146-165.

19. Al-Kheraif AA. The effect of mechanical and chemical polishing techniques on the surface roughness of heat-polymerized and visible light-polymerized acrylic denture base resins. Saudi Dent J 2014;26:5662.

20. Consani RLX, Pucciarelli MGR, Mesquita MF, Nogueira MCF, Barao VAR. Polymerization cycles on hardness and surface gloss of denture bases. Int J Contemporary Dent and Med Reviews 2014;ID 041114:1-6.

21. Mori K, Tsuji M, Ueda T, Sakurai K. Color and gloss evaluation of titanium dioxide coating for acrylic resin denture base. J Prosthodont Res 2015;59:249-253.

22. Rizzatti-Barbosa CM, Ribeiro Silva MC. Influence of double flask investing and microwave heating on the superficial porosity, surface roughness and Knoop hardness of acrylic resin. J Prosthodont 2009;18:503-506.

23. Consani RL, Domitti SS, Consani S. Effect of a new tension system, used in acrylic resin flasking, on the dimensional stability of denture bases. J Prosthet Dent 2002;88:285-289.

24. Santos MBF, Consani RLX, Mesquita MF. Influence of different metal flask systems on tooth displacement in complete upper dentures. Gerodontology 2012;29:30-35.

25. Farias Neto A, Sousa RL, Rizzatti-Barbosa CM. The influence of double flask investing on tooth displacement in dentures processed by microwave irradiation. Gerodontology 2012;29:e924-929.

Received November 6, 2015 Accepted February 17, 2016 